\title{
Selenium prevents lipid peroxidation in liver and lung tissues of rats in acute swimming exercise
}

\author{
Akil Mㄴ, Gurbuz $\mathrm{U}^{2}$, Bicer $\mathrm{M}^{3}$, Halifeoglu I${ }^{4}$, Baltaci AK ${ }^{5}$, Mogulkoc $\mathrm{R}^{5}$ \\ Usak University, High School of Physical Education and Sports, Usak, Turkey. rasimmogulkoc@yahoo.com
}

\begin{abstract}
Background: Selenium, which is critical for human health, is necessary for various metabolic processes, including thyroid hormone metabolism, protection against oxidative stress, and immune function.

Objective: The present study aims to examine how selenium administration affects lipid peroxidation in liver and lung tissues of rats subjected to acute swimming exercise.

Methods: The study included 32 Spraque-Dawley adult male rats divided into Group 1 (general control), Group 2 (selenium-administered), Group 3 (swimming), and Group 4 (selenium-administered swimming). MDA and GSH levels were determined in liver and lung tissues.

Results: The highest MDA values in the liver and lung tissues were found in group 3 in the study. MDA value in group 4 was higher than those in groups 1 and 2. Group 4 had the highest liver and lung GSH levels. GSH levels in Group 3 were higher than those in groups 1 and 2.

Conclusion: Results of the study indicate that acute swimming exercise causes lipid peroxidation in liver and lung tissues, while selenium administration prevents free radical formation by increasing antioxidant activity (Tab. 2, Ref. 26). Text in PDF www.elis.sk.

Key words: selenium, exercise, lipid peroxidation, rat.
\end{abstract}

\section{Introduction}

Selenium (Se), which is found commonly in nature, is an essential trace element required for normal development of human and animal organisms $(1,2)$. Selenium was first discovered in sulfuric acid residues in 1818 by the Swedish chemist Berzelius (3). Selenium used to be regarded a toxic substance for a long time; the fact that it was needed by living organisms was discovered in 1957, when Schwartz and Foltz (4) showed that selenium deficiency had a part in the development of liver degeneration. In early 1960s, the role of selenium in human health started to attract increasingly more attention and it was then that research focused on human diseases that were similar to animal diseases responding to selenium (5). Although five decades have passed since the discovery that selenium was important for human nutrition, the daily need for selenium is still unknown. However, our knowledge of the necessary functional roles attributed to selenium, which has both short- and long-term effects on human health, is expanding daily (6). Selenium, which is critical for human health, is necessary for various metabolic processes including thyroid hormone me-

${ }^{1}$ Usak University, High School of Physical Education and Sports, Usak, Turkey, ${ }^{2}$ Selcuk University, School of Veterinary, Department of Food Hygene, Konya, Turkey, ${ }^{3}$ Gaziantep University, High School of Physical Education and Sports, Gaziantep, Turkey, ${ }^{4}$ Firat University, School of Medicine, Department of Biochemistry, Elazig, Turkey, and ${ }^{5}$ Selcuk University, School of Medicine, Department of Physiology, Konya, Turkey

Address for correspondence: R. Mogulkoc, MD, Selcuk University, Medical School, Department of Physiology, 42075, Konya, Turkey. Fax: +90.332.2412184 tabolism, protection against oxidative stress, and immune function (6). Selenium is a molecule that activates glutathione peroxidase, and is therefore involved in antioxidant mechanisms preventing oxidative damage $(7,8)$. Exhaustive physical exercise in animals is known to lead to oxidative damage probably by stimulating free radical production in many tissues, including muscle, liver, heart and lung tissues (9). The facts that oxidative stress increases in exercise and selenium is known to stimulate antioxidant activity (10) suggest an inevitable relation between selenium and exercise. The present study aims to examine how selenium administration affects lipid peroxidation in liver and lung tissues of rats subjected to acute swimming exercise.

\section{Methods}

This study was carried out on 32 Spraque-Dawley adult male rats provided by the Experimental Medicine Application and Research Center of Selcuk University in the Experimental Animals Unit of the Selcuk University, Faculty of Veterinary Medicine. The study protocol was approved by the Ethics Committee of the concerned university.

The experimental animals used in the study were divided into 4 groups, each having an equal number of rats.

Group 1: General control group where no procedure was applied.

Group 2: Selenium-supplemented control group. The group was administered intraperitoneal $0.6 \mathrm{mg} / \mathrm{kg}$ sodium selenite for 4 weeks.

Group 3: Swimming control group. The group was administered no dietary supplement and was subjected to a 30-minute acute swimming exercise at the end of the procedures. 
Group 4: Selenium-supplemented swimming group. The group was administered intraperitoneal $0.6 \mathrm{mg} / \mathrm{kg}$ sodium selenite for 4 weeks and was subjected to a 30-minute acute swimming exercise at the end of the procedures.

The experimental animals were fed about $10 \mathrm{~g}$ standard rat pellet per 100 g per body weight daily. They were kept in an environment under light/dark 12-hour cycles and standard room temperature $\left(21 \pm 1^{\circ} \mathrm{C}\right)$. All the injections were given at 9.00-10.00 a.m. At the end of the 4-week procedure, all animals were sacrificed by decapitation at 9.00-10.00 a.m. to collect and analyze liver and lung samples. Collected tissue samples were stored at $-80{ }^{\circ} \mathrm{C}$ until the analysis time.

\section{Experimental procedures}

Sodium selenite supplementation

For selenium supplementation (Natriumselenite-Pentahydrate, Merck KGaA 64271 Dramstadt, Germany), selenium was dissolved in distilled water and supplemented in form of intraperitoneal dose of $0.5 \mathrm{ml}$ serum physiologic, so that each rat received 0.6 $\mathrm{mg} / \mathrm{kg}$ sodium selenite/day. The supplementation was performed at the same hour (9:00 a.m.) for 4 weeks.

\section{Swimming exercise}

The exercise was performed in a heat-resistant glass swimming pool, $50 \mathrm{~cm}$ in length and width, with a thermostat keeping the temperature fixed at $37^{\circ} \mathrm{C}$. The exercise was performed once for 30 minutes, 24 minutes after the end of procedures. The experimental animals were made to swim in pairs, and then they were decapitated to collect blood samples for analysis.

\section{Biochemical analyses}

Tissue MDA analyses

In order to obtain a $10 \%$ homogenate, liver and lung tissue samples were homogenized at $+4{ }^{\circ} \mathrm{C}$ with $150 \mathrm{mMol} \mathrm{KCl}$ (Microsan Ultrasonic Cell Disruptor Misonic). A volume of $2 \mathrm{ml}$ $\mathrm{HClO}_{4}$ was added to $2 \mathrm{ml}$ homogenate and centrifuged at 3,000 rpm for 15 minutes. MDA level was evaluated in the supernatant. Then, $3 \mathrm{ml} \mathrm{H}_{3} \mathrm{PO}_{4}, 1 \mathrm{ml} \mathrm{0.675 \%}$ thiobarbituric acid and $0.5 \mathrm{ml}$ from the homogenate were mixed and kept in a boiling water bath for 45 minutes. MDA levels were read at $532 \mathrm{~nm}$ and determined as nmol/gram/protein (11).

\section{Tissue GSH determination}

In order to obtain a $10 \%$ homogenate, liver and lung tissue samples were homogenized at $+4{ }^{\circ} \mathrm{C}$ with $150 \mathrm{mMol} \mathrm{KCl}$ (Microsan Ultrasonic Cell Disruptor Misonic) and centrifuged at $3000 \mathrm{rpm}$ for 15 minutes. Level of GSH in the supernatant was determined by Ellmann method. Tissue protein concentration was determined using biuret method. GSH level was established as $\mathrm{mg} / \mathrm{g} /$ protein (12).

\section{Statistical evaluations}

A computer software package was used in the statistical evaluation of results. Arithmetic means and standard errors of all other parameters were calculated. Variance analysis was used to deter-
Tab. 1. MDA levels in liver and lung tissues of study groups $(\mathrm{nmol} / \mathrm{ml})$.

\begin{tabular}{lcc}
\hline Groups $(\mathrm{n}=8)$ & Liver MDA & Lung MDA \\
\hline 1 General Control & $52.73 \pm 17.31^{\mathrm{C}}$ & $43.47 \pm 13.78^{\mathrm{C}}$ \\
2 Selenium Supplemented Control & $47.28 \pm 9.32^{\mathrm{C}}$ & $38.73 \pm 10.77^{\mathrm{C}}$ \\
3 Swimming Control & $86.95 \pm 19.29^{\mathrm{A}}$ & $70.47 \pm 19.78^{\mathrm{A}}$ \\
4 Selenium Supplemented Swimming & $78.15 \pm 9.22^{\mathrm{B}}$ & $62.65 \pm 12.07^{\mathrm{B}}$ \\
\hline * Means with different superscripted letters in the same column have statistical sig- \\
nificance $(\mathrm{p}<0.001)$
\end{tabular}

Tab. 2. GSH levels in liver and lung tissues of study groups (mg/dl).

\begin{tabular}{lcc}
\hline Groups (n=8) & Liver GSH & Lung GSH \\
\hline 1 General Control & $34.85 \pm 10.47^{\mathrm{C}}$ & $16.25 \pm 5.12^{\mathrm{C}}$ \\
2 Selenium Supplemented Control & $37.24 \pm 11.77^{\mathrm{C}}$ & $17.61 \pm 6.09 \mathrm{C}$ \\
3 Swimming Control & $63.81 \pm 14.76^{\mathrm{B}}$ & $34.18 \pm 9.84^{\mathrm{B}}$ \\
4 Selenium Supplemented Swimming & $78.33 \pm 15.71^{\mathrm{A}}$ & $46.91 \pm 10.69^{\mathrm{A}}$ \\
\hline
\end{tabular}

* Means with different superscripted letters in the same column have statistical significance $(\mathrm{p}<0.001)$

mine differences between groups. The Least Significant Difference (LSD) Test was employed to compare group means in the statistically significant variance analysis results. Differences for which $\mathrm{p}<0.05$ were accepted significant.

\section{Results}

The highest MDA values in liver and lung tissues were found in group 3 ( $p<0.001$ ). MDA value in group 4 was higher than those in groups 1 and 2 ( $p<0.001)$. MDA values in the liver and lung tissue samples of groups 1 and 2 did not differ (Tab. 1). Group 4 had the highest liver and lung GSH level ( $p<0.001)$. GSH level in group 3 was higher than the levels in groups 1 and 2 ( $<<0.001)$. There was no difference between GSH levels in the liver and lung tissues in groups 1 and 2 (Tab. 2).

\section{Discussion}

In the present study the highest MDA levels in liver and lung tissues were found in the swimming control group (group 3). Despite the presence of conflicting data, it is accepted that physical exercise enhances the formation of free radicals (13). Intense physical activity was shown to lead to oxidative damage in the blood and various tissues of not only humans, but also animals $(14,15)$. Elevated MDA levels we obtained in the swimming control group (group 3) in our study are consistent with the results of the above-cited researchers. MDA levels in liver and lung tissues of the selenium-supplemented swimming group (group 4) were significantly lower than the levels in the swimming control group (group 3), but higher than those in the general control (group 1) and selenium-supplemented control (group 2) groups. Ji et al (16) showed that acute exercise significantly elevated MDA levels in the liver mitochondria of selenium-deficient rats. It was reported that oxidative damage that was observed in the blood and tissues of rats in exercise was due to the suppression of antioxidant activity by selenium deficiency (17). Zamora et al (18) noted that selenium supplementation reduced oxidative damage in acute and chronic exercise, but that the mechanism of this effect at the mitochondrial 
level was unclear. Results of these researchers lend support to the reduced MDA levels we obtained in group 4, relative to group 3 in our study. In the present study, MDA levels of the general control (group 1) and selenium-supplemented control (group 2) groups were not different, while both were lower than the levels in groups 3 and 4. Lower MDA levels in groups 1 and 2 are associated with the lack of physical activity, that is, the sedentary status of both.

The highest liver and lung GSH levels were established in the selenium-supplemented swimming group (group 4). According to Emre et al (19), endogenous activation of the GSH system in exercise is an adaptive mechanism preventing the formation of free radicals. Selenium plays a role in the structure of the GSH system $(20,21,22)$. When these data are considered collectively, it is not surprising that selenium supplementation to rats subjected to acute swimming exercise elevates GSH levels in liver and lung tissues. Although indirectly, the fact that Ji et al (17) demonstrated a significant decrease in GSH levels and antioxidant activity in general due to selenium deficiency lends support to the elevated GSH levels we obtained in group 4 of our study. GSH values we found in the swimming control group (group 3) were lower than the values in group 4 (selenium-supplemented swimming) but higher than those in groups 1 and 2. Both free radical production and antioxidant activity increase with exercise. It is still controversial whether this increase is associated with the duration of exercise or not $(21,23)$. It was reported that exercise prevented the damage caused by free radicals in rats (16). It was also reported that aerobic exercise mildly reduced free radical formation (24), and similarly, that antioxidant activity was stimulated in response to exercise (25). The fact that Veera Reddy et al (26) noted an increase in antioxidant enzymes in response to exercise is consistent with the elevated GSH levels we found in group 3.

Results of the study indicate that acute swimming exercise causes lipid peroxidation in liver and lung tissues, but selenium supplementation prevents free radical formation by enhancing antioxidant activity.

\section{References}

1. Shamberger RJ. Selenium metabolism and function. Clin Physiol Biochem 1986; 4: 42-49.

2. Shu H. Human selenium deficiency during total parenteral nutrition support (a case report). Zhongguo Yi Xue Ke Xue Yuan Xue Bao 1989; 11: 74-76.

3. Oldfield JE. The two faces of selenium. J Nutr 1987; 117: 2002-8200.

4. Schwartz K, Foltz SM. Se as an integral part of factor 3 against necrotic liver degeneration. J Mountain Chemical Society 1957; 79: 292-293.

5. Combs SB, Combs GF. The role of selenium in nutrition. Orlando FL, Academic Press Inc. 1986; 347-367.

6. Brown KM, Arthur JR. Selenium selenoproteins and human healt: a review. Public Health Nutrition 2001; 4: 593-599.

7. Holben DH, Smith AM. The diverse role of selenium within selenoproteins: a review. J Am Diet Assoc 1999; 99: 836-843.

8. Olivieri O, Girrelli D, Azzini M. Low selenium status in the elderly influences thyroid hormones. Clin Sci 1995; 89: 637-642.
9. Sen CK, Packer L. Thiol homeostasis and supplements in physical exercise J Am J Clin Nutr 2000; 72: 653-669.

10. Thomson CD. Assessment of requirements for selenium and adequacy of selenium status: a review. Eur J Clin Nutr 2004; 58: 391-402.

11. Draper HH, Hadley M. Malondialdehyde determination as index of lipid peroxidation. Methods Enzymol 1990; 186: 421-431.

12. Atroshi F, Sankari S, Osterberg S, Sandholm M. Variation of erythrocyte glutathione peroxidase activity in Finn sheep. Res Vet Sci 1981; 31: 267-271.

13. Kanter M. Free radicals, exercise and antioxidant supplementation. Proc Nutr Soc 1998; 57: 9-13.

14. Goldfarb AH, McIntosh MK, Boyer BT. Vitamin E attenuates myocardial oxidative stress induced by DHEA in rested and exercised rats. J Appl Physiol 1996; 80: 486-490.

15. Reddy KV, Kumar TC, Prasad M, Reddanna P. Pulmonary lipid peroxidation and antioxidant defenses during exhaustive physical exercise: the role of vitamin E and selenium. Nutrition 1998; 14: 448-451.

16. Ji LL, Stratman FW, Lardy HA. Antioxidant enzyme systems in rat liver and skeletal muscle. Influences of selenium deficiency, chronic training, and acute exercise. Arch Biochem Biophys 1988; 263: 150-160.

17. Ji LL, Stratman FW, Lardy HA. Antioxidant enzyme response to selenium deficiency in rat myocardium. J Am Coll Nutr 1992; 11: 79-86.

18. Zamora AJ, Tessier F, Marconnet P, Margaritis I, Marini JF. Mitochondria changes in human muscle after prolonged exercise, endurance training and selenium supplementation. Eur J Appl Physiol Occup Physiol 1995; 71: 505-511.

19. Emre MH, Duzova H, Sancak B, Polat A, Erdogan H, Yologlu S. Serum selenium response to maximal anaerobic exercise among sportsmen trained at various levels. J Trace Elem Exp Med 2004; 17: 93-100.

20. Helwig B. Selenium. Antioxidants and Exercise. graduate of the Department of Human Nutrition at Kansas State University, under the supervision of Dr. Katherine Grunewald, graduate thesis 2000.

21. Ortenblad N, Madsen K, Djurhuus MS. Antioxidant status and lipid peroxidation after shortterm maximal exercise in trained and untrained humans. Am J Physiol 1997; 272: R1258-1263.

22. Tiidus PM. Radical species in inflammation and overtraining. Can J Physiol Pharmacol 1998; 76: 533-538.

23. Powers SK, Ji LL, Leeuwenburgh C. Exercise training-induced alterations in skeletal muscle antioxidant capacity: a brief review. Med Sci Sports Exerc 1999; 31: 987-997.

24. Kim HT. Effect of the joint administration of selenium and vitamin $E$ in combination with regular aerobic exercise on markers of lipid peroxidation and glutathione peroxidase in diabetic rats. Int J Sport Nutr Exerc Metab 2005; 15: 266-278.

25. Tessier F, Hida H, Favier A, Marconnet P. Muscle GSH-Px activity after prolonged exercise, training, and selenium supplementation. Biol Trace Elem Res 1995; 47: 279-285.

26. Veera Reddy K, Charles Kumar T, Prasad M, Reddanna P. Exercise-induced oxidant stress in the lung tissue: role of dietary supplementation of vitamin E and selenium. Biochem Int 1993; 26: 863-871.

Received September 23, 2013. Accepted October 1, 2013. 